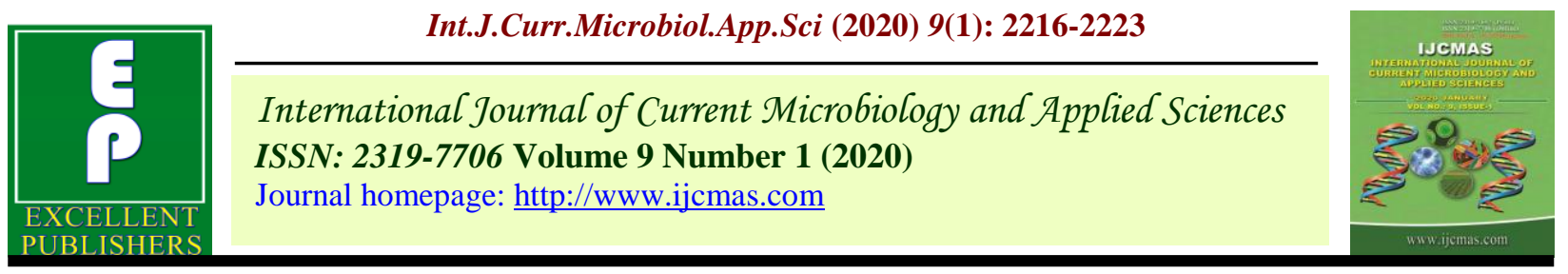

Original Research Article

https://doi.org/10.20546/ijcmas.2020.901.251

\title{
An Impact Assessment of Front Line Demonstrations on Yield and Economics of Foxtail Millet under Rainfed Conditions of Hadagali Taluka
}

\author{
N. H. Sunitha ${ }^{1 *}$, Hanumanthppa Shrihari ${ }^{2}$ and Manjunath Banuvally ${ }^{3}$ \\ Agricultural Extension Education Centre, Huvinahadagali \\ University of Agricultural sciences, Raichur, India
}

\begin{tabular}{|l|}
\hline K e y w o r d s \\
Small millets, \\
Frontline \\
demonstration, \\
Technology gap, \\
Extension gap, B : \\
C ratio \\
\hline Article Info \\
\hline $\begin{array}{l}\text { Accepted: } \\
22 \text { December } 2019 \\
\text { Available Online: } \\
\text { 20 January } 2020\end{array}$ \\
\hline
\end{tabular}

Keywords

Small millets,

Frontline

Technology gap,

Extension gap, B :

C ratio

Article Info

Accepted:

Available Online:

\section{A B S T R A C T}

Millets are more nutritious and have a lower glycemic index than rice and wheat, but factors like lack of improved varieties, agronomical packages and practices as well as unorganized seed system are constraining production and productivity. Therefore, the present study was carried out to know the yield gaps between improved practices and farmers' practices under Front Line Demonstrations (FLDs) of foxtail millet under rainfed conditions of Huvinahadgali Taluka Districts of Bellari. A total of 50 farmers were selected for frontline demonstrations in the Taluka, of which 20 ha land was covered by high yielding Foxtail millet (HN-46, HMT 100-1) varieties over the last five years. The conducted FLDs made a very positive and significant impact on grain as well as on fodder yield of foxtail millet that ranged from 11.40 to 24.26 per cent overall increase respectively was recorded during the last five years. The higher technological gap (4.00 to $7.24 \mathrm{qtl} / \mathrm{ha}$ ), extension gap (4.18 to $9.32 \mathrm{qtl} / \mathrm{ha}$ ) and technological index (9.41 to $13.70 \%)$ in the crop indicating that there is an urgent need of dissemination of location specific suitable package of practices. The data revealed that the conducted FLDs also enhanced the farmer's income by increasing B: C ratio that ranged from 2.4 to 3.2 in both the crops. The impact of such demonstrations are quite strong as it is also visible from the fact that barnyard millet variety HN-46, HMT-100-1 has been one of the most accepted varieties by farmers of Bellari District for the last more than ten years and has been constantly under FLD programme.

\section{Introduction}

Millets have been called "Nutri grains" since they are rich in micro nutrients like minerals and B complex vitamins. Small millets have gained their attention owing to their inherent capacity of early maturity, higher yields due to C4 plant type, capacity to yield even in poor soil under low rainfall and poor management conditions; hence they are popularly known as "climate resilient" crops in Indian agriculture. Small millets provide much needed food and fodder security of the nation. Among minor millets, foxtail millet 
have low glycemic index. Consumption of these grains has demonstrated positive health benefits among the diabetics and they are known as "wonder grains". Foxtail millet can be planted when it is too late to plant most other crops. It keeps growing at $300-400$ $\mathrm{mm}$ annual rainfall also in semi arid areas. In kharif season Millets are one of the cereals besides the major wheat, rice, and maize. Millets are major food sources for millions of people, especially those who live in hot and humid areas of the world. They are grown mostly in marginal areas under agricultural conditions in which major cereals fail to give substantial yields1. Millets are important foods in many under developed countries because of their ability to grow under adverse weather conditions. Crop farming in the Arid and Semi-arid Lands (ASALs) is a big challenge due to factors such as the harsh climatic conditions experienced there, low adoption of improved drought tolerant crop varieties and limited farmer's knowledge on appropriate agricultural technologies. These factors contribute significantly to low food production, which leads to food insecurity persistently experienced in the ASALs, which are home to about a third of the world's population5.

Upadhyaya et al., ${ }^{13}$ stated that the small millets are under-utilized crops and continued to be neglected in terms of support for production, promotion, research and development. Their presence in the food basket has been declining over the years. One of the main reasons for this decline is the increased availability of other staple and commercial crops such as rice, wheat, maize, etc. as a result small millets are in a situation of crisis in India because a dramatic decrease from 1960 to 2009 in cultivated area (80\% for small millets, $46 \%$ for finger millet); 76 per cent decrease in total production of small millets which caused significant reduction in per capita availability of all millets (despite high productivity gains for some varieties); and a steep fall in overall millets consumption.

Millets occupy an important place in the agriculture of the poor and marginal farmers in Karnataka. Major production constraints include the low yield of existing varieties, poor seed quality and lack of access to improved varieties by farmers. Moreover, poor agronomic practices such as higher seed rate, faulty nutrient management and negligence of plant protection measures are responsible for low productivity. However, the demands of small millet and their product increasing day-by-day due to their nutritional values in national as well as international market. Therefore, to increase the farmer's field productivity, a modern concept was formulated by agricultural scientist called "frontline demonstration" with the objective to demonstrate newly released high yielding varieties, crop production and protection technologies and management practices at farmer's fields under different farming situations. While demonstrating the technologies in the farmer's fields, the scientists are required to study the various factors contributing higher crop yield, constraints in field production and thereby required to generate production data and feedback information. Keeping these in view, frontline demonstration of improved high yielding varieties with the thematic area to replace local seeds with high yielding improved variety seed on foxtail millet were conducted to enhance the seed replacement rate, productivity, economic returns and also convincing the farmers for adoption of newly developed high yielding varieties in foxtail millet.

\section{Materials and Methods}

The frontline demonstration is to demonstrate newly released crop production and protection 
technologies and their management practices in the farmers ${ }^{\text {ee }}$ field under different agroclimatic regions and farming situations.

\section{Objective}

The objective of Front Line Demonstration $\left(\mathrm{FLD}^{\mathrm{ee}} \mathrm{s}\right)$ is to demonstrate newly released crop production and production technologies and their management practices on the farmers $^{\text {ee }}$ field to constraints of production, factors contributing for higher production and thereby to generate production data and feedback information. The frontline demonstration is different from the normal demonstrations conducted by the extension functionaries. FLDs are conducted under the close supervision of the scientists.

\section{Locale of the study}

Bellari is one of the districts of Northern Karnataka. It receives low to moderate rain fall was selected as the locale of the study area and Agricultural Extension Education centre, Huvinahadagali conducted the FLDs on Foxtail millet. Major farming system is rainfed and irrigated. Average rainfall ranges from $635 \mathrm{~mm}$. in general soil types are black and red soil.

\section{Sampling design}

The study area covers three talukas of Bellari district, Huvinahadgali, Hagaribommanahalli, Kudligi. Villages were selected from each taluka randomly. Where FLDs were conducted during 2014-15, 2015-16, 2016-17, 2017-18 and 2018-19. The final sample of the study included 50 FLD farmers.

The demonstration was carried out under Frontline demonstration at AEEC hadagali during 2014 to 2019 during Kharif seasons. Before conducting the FLD, meetings with farmers, surveys and diagnostic visits were under taken for selection of the farmers and villages and after that an orientation training programme was imparted to the beneficiaries related to crop under demonstration. A total of 50 farmers were selected for frontline demonstrations in District of Bellari of which 20 ha land was covered by high yielding foxtail millet varieties during the five years. The quality seeds of foxtail millet variety SIA 2644, HN-46, HMT-100-1 variety were distributed to the selected famers under FLDs. During the FLDs from sowing to harvesting, frequent monitoring was carried out to monitor the adopted package of practices, timely sowing, effective plant protection and weed management in both the practices (farmers practice and improved practice) to keep all the remaining input same except seed.

The average yield of each FLD and farmers practice, cost of cultivation, gross return, net return and benefit cost ratio ( $\mathrm{B}: \mathrm{C}$ ratio) was taken for subsequent five years for interpretation of the results. The extension gap, technology gap and technology index were calculated using the following formula as suggested by Samui et al., ${ }^{8}$.

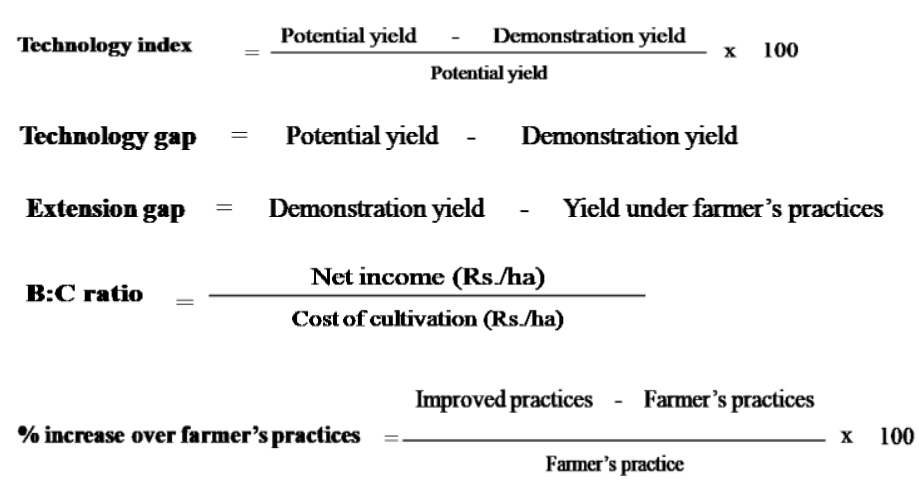

The demonstration conducted on various soils included improved seed, sowing method, balance use of fertilizer and plant protection measures under totally rainfed condition. During both the year the rainfall season remained normal. Crop variety $\mathrm{HN}-46$, HMT.100-1 and application of cabofuran- 3G 
was given to control stem borer. Crop was sown in the first fortnight of June and harvested in the first fortnight of November. Yield data were recorded from individual demonstration by harvesting 100 sq. m area. Similarly local yield was also recorded for comparison.

Jatav and Patel (2010) reported that the majority of the respondents (beneficiaries of FLD programme and non beneficiaries) possessed medium level of the scientific temperment .The mean value of scientific temperament of FLD beneficiaries eas higher than the mean score of scientific temperament of non beneficiaries.The test indicated that there is a significant difference between scores mean of both the group. Thus, it can be stated that, there is a positive impact of FLD programme on scientific temperament of wheat growers in Indore and Dewas district. Kirar et al., (2006) reported that frontline demonstration programme was effective in changing attitude, skill and knowledge of improved practices of HYV of urd including adoption this also improved the relationship between farmers and scientist and built confidence between them. The farmers who adopted demonstration acted also as source of information and pure seed for wider dissemination of HYV of urd for the farmers. The productivity gain under FLD over traditional practices of urd cultivation created greater awareness and motivated the other farmers to adopt appropriate production technology of urd in the district. The selection of critical input and participatory approach in planning and conducting the demonstration definitely help in the farmers of technology to the farmers. Singh et al., (2005) reported that the FLD was effective in changing the attitude, skill and knowledge of improved / recommended practices of high yielding variety of rice including adoption. Patel and Tunver (2004) reported that the yield of groundnut was increased 24.05 per cent after FLD as compared to before frontline demonstration. It shows a positive impact of FLD on adoption of recommended practices.

\section{Results and Discussion}

\section{Production constraints of foxtail millet}

During the FLDs, the problems faced by farmers in foxtail millet production were documented and the perusal data is presented in Table 1.

The major problems faced by farmers are wild animal damage $(80.17 \%)$ that causes the huge losses of crops followed by lack of high yielding varieties (77.31 \%), timely availability of quality seeds $(75.35 \%)$, marketing $(73.75 \%)$, low technical knowledge $(70.51 \%)$, use of higher seed rate $(42.67 \%)$ while diseases like grain smut in barnyard millet and Cercospora leaf spot in finger millet also observed by farmers as a major grain production constraint followed by insect. However the other production constraints observed during FLDs are limited possibility of mechanization to reduce the drudgery associated with production and postharvest operations, food of marginalized communities, although it is consumed by the majority of households in the mid and high regions in varying quantity, irrespective of ethnicity and lack of awareness on the nutrient composition and value of small millets on human health; consequently there is a low rate of consumption especially among the younger generation. Singh ${ }^{9}$ also conducted a frontline demonstration on wheat in Rudraprayag District of Uttarakhand and reported almost similar production constraints. Dhruw et al., ${ }^{4}$ has also reported similar constraints in maize.

\section{Extension gap}

The average extension grain yield gap for foxtail millet was calculated $5.14 \mathrm{qtl} / \mathrm{ha}$ over five years. However, fodder yield showed 
higher extension yield gap that varied from 4.18 to $9.32 \mathrm{qt} 1 / \mathrm{ha}$. The higher extension yield gap due to lack of awareness for the adoption of improved farm technologies by the farmers indicating that there is a strong need to aware and motivate the farmers for adoption of improved farm technologies in foxtail millet over existing local practices. Choudhary et $a l .,{ }^{2}$ argued that the refinement in the local farmers' practices for higher adoption of location specific generated farm technology for sustaining crop productivity is another option open for the research scientists whereas, the successful development, dissemination and adoption of improved technologies for small-holders depend on more than careful planning of research and the use of appropriate methodologies in extension as stated by Biggs and Smith ${ }^{1}$.

\section{Technology index}

The average technology index was quite higher in foxtail millet over five years as indicated by Table 2 . The technology index calculated for foxtail millet showed higher value that ranged from 15.00 to 30.00 per cent for grain yield while 9.6 to 17.03 per cent technology index was calculated for fodder yield. Poor field establishment at early vegetative stage due to water stress under rainfed farming with uneven rainfall distribution, long dry spell and increasing pressure of diseases and insect pests are the possible reason for poor yields causing higher technology index in both the crops. Technology index indicates the feasibility of generated farm technologies in the farmers' fields under existing agro-climatic conditions as stated by Vedna $e t$ al. ${ }^{14}$ and Choudhary $e t$ $a l .{ }^{2}$. Lower the technology index, higher is the feasibility of generated farm technology under farmers' fields and vice-versa. Similar results were also reported by Jeengar et al., ${ }^{5}$ in maize and Singh et al., ${ }^{10}$ in mustard.

Table.1 List of production constraints and their rank given by farmers

\begin{tabular}{|r|l|c|c|}
\hline $\begin{array}{r}\text { Sl. } \\
\text { No. }\end{array}$ & \multicolumn{1}{|c|}{ Major constraints } & Percentage & Rank \\
\hline $\mathbf{1}$ & Damage by wild animals & 80.17 & I \\
\hline $\mathbf{2}$ & Lack of high yielding varieties & 77.31 & II \\
\hline $\mathbf{3}$ & Timely availability of quality & 75.35 & III \\
\hline & seeds & & \\
\hline $\mathbf{4}$ & Marketing & 73.75 & IV \\
\hline $\mathbf{5}$ & Low technical knowledge & 70.51 & V \\
\hline $\mathbf{6}$ & Use of higher seed rate & 42.67 & VI \\
\hline $\mathbf{7}$ & Diseases of foxtail millet & 20.15 & VII \\
\hline $\mathbf{8}$ & Insect-pests of foxtail millet & 18.73 & VIII \\
\hline
\end{tabular}


Table.2 Impact of improved and farmers' practices on grain yield of foxtail millet under front line demonstration

\begin{tabular}{|c|c|c|c|c|c|c|c|c|c|c|c|c|c|c|c|c|}
\hline \multirow[t]{2}{*}{ Years } & \multirow{2}{*}{$\begin{array}{l}\text { Area } \\
\text { (ha) }\end{array}$} & \multirow{2}{*}{$\begin{array}{l}\text { No of } \\
\text { FLD }\end{array}$} & \multirow{2}{*}{$\begin{array}{c}\text { Potential } \\
\text { grain } \\
\text { yield }\end{array}$} & \multicolumn{3}{|c|}{ Grain yield (qtl/ha) } & \multicolumn{3}{|c|}{ Grain yield (qtl/ha) } & \multirow{2}{*}{$\begin{array}{c}\text { Potential } \\
\text { fodder } \\
\text { yield }\end{array}$} & \multicolumn{3}{|c|}{ Fodder yield (qtl/ha) } & \multicolumn{3}{|c|}{ Fodder yield } \\
\hline & & & & I.P. & F.P. & $\%$ & $\begin{array}{c}\text { TG } \\
\text { (qt//ha) }\end{array}$ & $\begin{array}{c}\text { EG } \\
\text { (qt//ha) }\end{array}$ & TI (\%) & & I.P. & F.P. & $\%$ & $\begin{array}{c}\text { TG } \\
\text { (qt//ha) }\end{array}$ & $\begin{array}{c}\text { EG } \\
\text { (qtl//ha) }\end{array}$ & TI (\%) \\
\hline 2014 & 4 & 10 & 25 & 17.64 & 12.50 & 29.14 & 29.44 & 5.14 & 7.36 & 42.5 & 38.42 & 29.10 & 24.26 & 4.08 & 9.32 & 9.6 \\
\hline 2015 & 4 & 10 & 25 & 21.25 & 14.25 & 32.94 & 15.00 & 7.00 & 3.75 & 42.5 & 36.68 & 32.50 & 11.40 & 5.82 & 4.18 & 13.70 \\
\hline 2016 & 4 & 10 & 25 & 17.5 & 12.50 & 28.57 & 30.00 & 5.00 & 7.50 & 42.5 & 35.26 & 28.68 & 18.67 & 7.24 & 6.58 & 17.03 \\
\hline 2017 & 4 & 10 & 25 & 20.25 & 12.75 & 37.03 & 19.00 & 7.50 & 4.75 & 42.5 & 38.50 & 31.50 & 18.18 & 4.00 & 7.00 & 9.41 \\
\hline 2018 & 4 & 10 & 25 & 18.5 & 12.56 & 32.19 & 26.00 & 5.94 & 6.50 & 42.5 & 37.80 & 29.68 & 21.48 & 4.70 & 8.12 & 11.06 \\
\hline
\end{tabular}

I.P.= Improved practices, F.P=Farmers practices, T.G=Technology Gap, E.G=Extension Gap and TI=Technology Index

Table.3 Economic analysis of demonstrated foxtail millet grown under improved practices and farmers practices

\begin{tabular}{|c|c|c|c|c|c|c|c|c|c|c|c|c|c|c|}
\hline \multirow[t]{2}{*}{ Year } & \multirow[t]{2}{*}{ Variety } & \multirow[t]{2}{*}{$\begin{array}{l}\text { No. of } \\
\text { Demo. }\end{array}$} & \multirow[t]{2}{*}{$\begin{array}{c}\text { Are } \\
\text { a } \\
(\mathbf{h a})\end{array}$} & \multicolumn{2}{|c|}{ Yield (q/ha) } & \multicolumn{2}{|c|}{$\begin{array}{c}\text { B:C } \\
\text { Ratio }\end{array}$} & \multirow[t]{2}{*}{$\begin{array}{c}\% \\
\text { increase } \\
\text { in yield }\end{array}$} & \multicolumn{2}{|c|}{$\begin{array}{c}\text { Cost of } \\
\text { cultivation } \\
\text { (Rs/ha ) }\end{array}$} & \multicolumn{2}{|c|}{$\begin{array}{l}\text { Gross returns } \\
\quad \text { (Rs. /ha) }\end{array}$} & \multicolumn{2}{|c|}{$\begin{array}{l}\text { Net returns } \\
\text { (Rs./ha) }\end{array}$} \\
\hline & & & & I.P. & F.P. & I.P. & F.P. & & I.P. & F.P. & I.P. & F.P. & I.P. & F.P. \\
\hline 2014-15 & SIA 2644 & 10 & 4 & 17.64 & 12.50 & 2.7 & 1.8 & 29.14 & 6810 & 6850 & 25561 & 19681 & 18751 & 12831 \\
\hline $2015-16$ & SIA 2644 & 10 & 4 & 21.25 & 14.25 & 2.7 & 1.9 & 32.94 & 7160 & 7160 & 26548 & 20717 & 19388 & 13557 \\
\hline 2016-17 & SIA 2644 & 10 & 4 & 17.5 & 12.50 & 2.4 & 1.7 & 28.57 & 7560 & 7560 & 26448 & 20827 & 18888 & 13267 \\
\hline 2017-18 & $\begin{array}{l}\text { HMT } \\
100-1\end{array}$ & 10 & 4 & 20.25 & 12.75 & 3.1 & 2.2 & 37.03 & 6945 & 6583 & 28674 & 21347 & 21729 & 14764 \\
\hline 2018-19 & $\begin{array}{l}\text { HMT } \\
100-1\end{array}$ & 10 & 4 & 18.5 & 12.56 & 3.2 & 2.1 & 32.19 & 6481 & 6410 & 27757 & 20497 & 21276 & 14087 \\
\hline
\end{tabular}

I.P. $=$ Improved practices, F.P=Farmers practices 


\section{Economics analysis}

Highest gross returns with $28,674 \mathrm{Rs}$./ha, net returns with 21729 Rs./ha and B:C ratio with 3.2 were calculated under improved practices while under farmers' practices highest gross returns with 21347 Rs./ha, net returns with 14,764 Rs./ha and B:C ratio with 2.2 were observed across the years for foxtail millet (Table 3). The variations between the years in the economic returns may be attributed to the variable performance of respective crops in terms of grain yield under improved practices in frontline demonstration. Higher returns and $\mathrm{B}: \mathrm{C}$ ratio under improved practices in frontline demonstration was also reported by Thakur et al., ${ }^{11}$, in finger millet crop, similarly higher net returns and $\mathrm{B}: \mathrm{C}$ ratio in the FLDs on improved technologies compared to the farmers practices reported by Joshi et al., ${ }^{6}$ in wheat.

In conclusion, the grain as well as fodder yield under improved practices was recorded higher than the farmers' practices, which not only increased the yield per unit area but also enhanced the farmers' income. However, a wide gap in potential yields, demonstration yields and farmers plot yields under both the crops due to technological and extension gaps indicating that there is a need of proper dissemination of location specific technologies imbedded with high yielding varieties to improve productivity and profitability of rainfed farming of Huvinahadagali Taluka.

\section{References}

Adekunle, A. A. (2012). In: Agricultural innovation in sub-saharan Africa: experiences from multiple stake holder approaches. Forum for Agricultural Research in Africa, Ghana. ISBN 97899881.8373.

Anon. (2009). Food and Agriculture
Orgainisation FAO. Sub-Saharan Africa Challenge Programme. Research plan and Programme for Impact assessment. Accra, Ghana.

Anon. (2010). Food and Agriculture Orgainisation. The State of Food Insecurity in the World, Addressing Food Insecurity in Protracted Crises. Rome, Italy.

B.Himasree et.al. (2017) Evaluation of remunerative foxtail millet (Setaria italika L.) based intercropping systems under late sown conditions, Bulletin of environment, Pharmacilogy and life sciences, Vol.6, Slp issue(1), 306:308.Samui, S.K., Mitra, S., Roy, D.K.,Mandal, A.K and Saha, D., Evaluation of frontline demonstration on groundnut. Indian Soc. Coastal Agric Res., 18(2):180-183(2000)

Biggs, S.D. and Smith, G., Beyond methodologies: Coalitionbuilding for participatory technology development. World Dev. 26: 239-248 (1998).

Choudhary, A.K., Yadav, D.S. and Singh, A., Technological and extension yield gaps in oilseeds in Mandi district of Himachal Pradesh. Ind. J. Soil Cons., 37(3): 224-229 (2009b).

Dhaka, B.L., Meena, B.S. and Suwalka, R.L., Popularization of improved maize production technology through frontline demonstrations in southeastern Rajasthan. J. Agril. Sci. 1(1): 39-42 (2010).

Dhruw, K.S., Sengar, R.S. and Yadav, K.N., Level of knowledge and adoption about recommended maize production technology. Agril. Update 7(3\&4): 311315 (2012).

Jeengar, K.L., Panwar, P. And Pareek, O.P., Front line demonstration on maize in Bhilwada district of Rajasthan. Current Agriculture, 30(1/2): 115-116 (2006).

Joshi, N.S., Bariya, M.K. and Kunjadia, B.B., 
Yield gap analysis through front line demonstrations in wheat crop. International J. Scientific Res. Pub. 4(9): 1-3 (2014).

Saleh, A. S., Zhang, Q., Chen J. and Shen Q., Millet Grains: Nutritional Quality, Processing, and Potential Health Benefits. Comprehensive Reviews in Food Science and Food Safety, 12: 281-295 (2013).

Samui, S.K., Mitra, S., Roy, D.K., Mandal, A.K. and Saha, D., Evaluation of front line demonstration on groundnut. J. Indian Soc. Coastal Agric. Res., 18(2): 180-183 (2000).

Singh, S. B., Impact of frontline demonstrations on yield of wheat (Triticum aestivum) under rain fed condition in Uttarakhand. Inter. J. Sci., Envi. Technol. 6(1): 779 - 786 (2017).

Singh, S.N., Singh, V.K., Singh, R.K. and Singh R. K., Evaluation of on-farm frontline demonstrations on the yield of mustard in Central Plain Zone of Uttar Pradesh. Indian Res. J.Ext.Edu. 7(2\&3): 79-81 (2007).

Thakur, A. K., Kumar P. and Yadav, S. C., Impact of Front Line Demostration (FLD) on the Yield and Economics of Small Millet on Bastar District of
Chhattisgarh, India. Int.J.Curr.Microbiol.App.Sci. 6(9): 1489-1497 (2017).

Ushakumari, S. R., Shrikantan, L. and Malleshi N. G., The functional properties of popped, flaked, extruded and roller dried foxtail millet (Setaria italica). Inter. J. Food Sci. Technol. 39: 907-915 (2004).

Upadhyaya, H. D., Vetriventhan, M., Dwivedi, S. L., Pattanashetti, S. K. and Singh, S. K., Proso, barnyard, little and kodo millets. In:Mohar Singh and HD Upadhyaya (eds) Genetic and Genomic Resources for Grain Cereals Improvement. Oxford: Academic Press, Elsevier, pp 321343 (2015).

Vedna, K., Kumar, A., Kumar, A. and Bhateria, S., Demonstration - an effective tool for increasing productivity of rapeseed- mustard in Kangra district of Himachal Pradesh. Himachal J. Agril. Res. 33(2): 257261 (2007).

Yadav, R. and Yadav, V. P., Harnessing productivity potential of small millets in Himalayan Hills. Indian Res. J. Ext. Edu. 9(1): 62-64 (2009).

\section{How to cite this article:}

Sunitha, N. H., Hanumanthppa Shrihari and Manjunath Banuvally. 2020. An Impact Assessment of Front Line Demonstrations on Yield and Economics of Foxtail Millet under Rainfed Conditions of Hadagali Taluka. Int.J.Curr.Microbiol.App.Sci. 9(01): 2216-2223. doi: https://doi.org/10.20546/ijcmas.2020.901.251 